\title{
The molecular events occur during MK-801-induced cytochrome oxidase subunit II down-regulation in GT1-7 cells
}

\author{
Tzu-Ying Lee, Ke-Li Tsai ${ }^{1}$, Wen-Sen Lee ${ }^{1,2}$ and Chin Hsu' \\ College of Medicine, Graduate Institute of Medicine, Kaohsiung Medical University, Kaohsiung 807, Taiwan, ROC \\ ${ }^{1}$ Department of Physiology, College of Medicine, Kaohsiung Medical University, Kaohsiung 807, Taiwan, ROC \\ ${ }^{2}$ Medical College, Graduate Institutes of Medical Sciences and Neuroscience, Taipei Medical University, 250 Wu-Hsing Street, Taipei 110, Taiwan, ROC \\ (Requests for offprints should be addressed to W-S Lee; Email: wslee@tmu.edu.tw, C Hsu; Email: chinhsu@cc.kmu.edu.tw)
}

\begin{abstract}
Previously, we showed that predominant expression of the $N$-methyl-D-aspartate (NMDA) receptor in the neurons of the sexually dimorphic nucleus of the preoptic area of male rats plays an important role in preventing neurons from apoptosis during sexual development. Blocking of the NMDA receptor by dizocilpine $((+)-5$-methyl-10,11-dihydro-5H-dibenzo[a,d] cyclohepten-5,10-iminemaleate (MK-801) causes down-regulation of some survival-related genes including cytochrome oxidase subunit II (COII), a mitochondria-encoded complex IV subunit, which in turn induces ATP depletion and the occurrence of apoptosis. The aim of this study is to investigate the molecular events during down-regulation of the COII gene expression induced by blocking of the NMDA receptor. Treatment of the GnRH cell line (GT1-7) with MK-801 caused 1) a decrease of intracellular calcium concentration $\left(\left[\mathrm{Ca}^{2+}\right]_{\mathrm{i}}\right)$ after $\left.20 \mathrm{~h} ; 2\right)$ significant decreases of the levels of peroxisome proliferator-activated receptor $\gamma$ coactivator-1 (PGC-1) mRNA and protein after $24 \mathrm{~h}$; 3 ) down-regulation of COII mRNA after $36 \mathrm{~h}$; and 4) the occurrence of neuronal apoptosis after $48 \mathrm{~h}$. Accordingly, we hypothesize that blocking of the NMDA receptor may cause a decrease of the $\left[\mathrm{Ca}^{2+}\right]_{\mathrm{i}}$, which in turn inhibits the expressions of PGC-1 and COII and then leads to subsequent neuronal apoptosis.
\end{abstract}

Journal of Molecular Endocrinology (2007) 39, 53-66

\section{Introduction}

Activation of the $N$-methyl-D-aspartate (NMDA) receptor may be critical for neuronal survival during a certain period of the brain development (Hwang et al. 1999). Blocking of the NMDA receptor by MK-801 (dizocilpine), a noncompetitive NMDA receptor antagonist, has been shown to promote cell death in the developing brain (Ikonomidou et al. 1999), suggesting that physiological activation of the NMDA receptor is an important regulator of neuron survival (Fiske \& Brunjes 2001). The apoptotic incidence of neurons in the sexually dimorphic nucleus of the preoptic area (SDN-POA) of male rats is significantly increased when the NMDA receptor is blocked by MK-801 (Hsu et al. 2001). Recently, we reported that some neurotropic genes (RNA binding motif protein 3 (RBM3), cytosolic phosphoprotein (P19), cytoskeletal $\gamma$ actin, and $\alpha$-tubulin) as well as survival-related genes ( $B c l-2$, cytochrome oxidase subunits II, III (COII), (COIII), and cytochrome $b$ ) in SDN-POA of neonatal male rats were significantly down-regulated when the NMDA receptor was blocked (Hsu et al. 2005).

COII, a mitochondria-encoded subunit of complex IV (Wong-Riley 1989, Zhang \& Wong-Riley 2000), is an enzyme involved in the mitochondrial electron transport chain that catalyzes the transfer of electrons to generate ATP via the coupled process of oxidative phosphorylation (Capaldi 1990b). Abnormal mitochondrial respiratory chain function due to genetic defects or chemical disruption results in a deficiency in ATP generation and subsequent cell death (Chandra et al. 2002). It has been suggested that ATP depletion caused by COII reduction may play an important role in the hypoxia-induced apoptotic cell death (Bae et al. 1998). However, the molecular mechanism underlying MK-801-induced COII suppression is still unclear.

The transcription of mitochondrial DNA-encoded genes such as COII could be activated by mitochondrial transcriptional factor A (mtTFA; Tfam; Dong et al. 2002, Vijayasarathy et al. 2003), which could be induced by raising cytosolic $\mathrm{Ca}^{2+}$ concentrations (Ojuka et al. 2003). Activation of the NMDA receptor may elevate cytosolic $\mathrm{Ca}^{2+}$ concentrations via extracellular calcium influx (Dayanithi et al. 1995), subsequently activates calcium/ calmodulin-dependent protein kinase IV (CaMKIV; See et al. 2001) and induces the expression of proliferatoractivated receptor $\gamma$ coactivator-1 (PGC-1; Wu et al. 2002) as well as the nuclear respiratory factor (NRF-2), a transcriptional activator of mtTFA (Wu et al. 1999, 2002, Ojuka 2004). On the other hand, blocking of the NMDA and 
alpha-amino-3-hydroxy-5-methyl-4-isoxazolepropionic acid (AMPA)/kainite receptor may produce neuronal apoptosis due to $\mathrm{Ca}^{2+}$ deficiency (Yoon et al. 2003). Accordingly, we hypothesize that blocking of the NMDA receptor may cause a decrease in intracellular $\mathrm{Ca}^{2+}$ concentration, which in turn inhibits the gene expression of PGC-1 and NRF-2, and finally leads to the suppression of COII expression and neuronal apoptosis. The present study was designed to investigate the possible signaling pathway of NMDA receptor-mediated regulation of COII gene expression in mitochondria.

\section{Materials and methods}

\section{Cell cultures}

The immortalized GT1-7 cells, which express the NMDA receptor (NMDAR) and mitochondrial COII genes (Lawson et al. 1995), were derived from hypothalamic gonadotrophin-releasing hormone $(\mathrm{GnRH})$ neurons and generously provided by Dr Ke-Wen Dong (The Jone Institute for Reproductive Medicine, East Virginia Medical School). The cells were cultured in Dulbecco's Modified Eagle's Medium $(4.5 \mathrm{mg} / \mathrm{ml}$ glucose, $0.6 \mathrm{mg} / \mathrm{ml} \mathrm{L-gluta-}$ mine, $3.7 \mathrm{mg} / \mathrm{ml} \mathrm{NaHCO}$ ), supplemented with $15 \%$ fetal calf serum, 100 units $/ \mathrm{ml}$ penicillin and $100 \mu \mathrm{g} / \mathrm{ml}$ streptomycin (Gibco), at $37^{\circ} \mathrm{C}$ in a humidified air containing $5 \%$ $\mathrm{CO}_{2}$ (Urbanski et al. 1994, Yang et al. 2003). Media were changed every other day. The cells were grown until $60 \%$ confluence and then treated with MK-801 at a concentration of $10^{-2}$ or $10^{-3} \mu \mathrm{M}$ for the indicated time intervals.

\section{Intracellular calcium measurement by flow cytometry}

The levels of intracellular free $\mathrm{Ca}^{2+}\left(\left[\mathrm{Ca}^{2+}\right]_{\mathrm{i}}\right)$ were analyzed using a calcium-sensitive fluorescence dye Fluo-3 (Molecular Probe Inc., Carlsbad, CA, USA; June \& Rabinovitch 1994, Yoon et al. 2003). Cells were plated at a density of $1 \times 10^{5}$ cells $/ \mathrm{cm}^{3}$ in a $25 \mathrm{~T}$ flask, maintained for 1 day, and then treated with MK-801 $\left(10^{-2}\right.$ or $\left.10^{-3} \mu \mathrm{M}\right)$ for the indicated time intervals. Cells were then trypsinized $(0 \cdot 25 \%$ trypsin, $0 \cdot 02 \%$ EDTA in calcium-magnesium free Hank's A solution) for $1 \mathrm{~min}$ and centrifuged at 1500 r.p.m for $5 \mathrm{~min}$ at $4{ }^{\circ} \mathrm{C}$. The cell pellets were resuspended in $1 \mathrm{ml}$ Hank's A solution, $5 \mu \mathrm{M}$ Fluo-3 AM dye added, and then incubated at $37^{\circ} \mathrm{C}$ in a $\mathrm{CO}_{2}$ incubator for $30 \mathrm{~min}$ with gentle mixing every $10 \mathrm{~min}$. After being centrifuged at 1500 r.p.m for $5 \mathrm{~min}$ at $4{ }^{\circ} \mathrm{C}$, the cell pellets were washed twice with $1 \mathrm{ml}$ Hank's A solution, and resuspended in $1 \mathrm{ml}$ Hank's A solution. The green fluorescence of Fluo-3 was excited at $488 \mathrm{~nm}$ and the emission $(525 \mathrm{~nm})$ was detected using Beckman Coulter flow cytometry (Burchiel et al. 2000) and then analyzed by software (WinMDI 2.8; Becton Dickinson Immunocytometry System, San Jose, CA, USA).

\section{Isolation of total RNA}

The GT1-7 cells were homogenized in TRI-Reagent (Molecular Research Center Inc., Cincinnati, OH, USA). After homogenization, $200 \mu \mathrm{l}$ chloroform per $1 \mathrm{ml}$ TRI-Reagent was added and mixed well. The mixture was then incubated at room temperature for $10 \mathrm{~min}$. The aqueous phase was separated after centrifugation at 12000 r.p.m for $15 \mathrm{~min}$ at $4{ }^{\circ} \mathrm{C}$ and the total RNA was precipitated with $500 \mu \mathrm{l}$ isopropanol. The total RNA was pelleted by centrifugation at 12000 r.p.m for $8 \mathrm{~min}$ at $4^{\circ} \mathrm{C}$, washed with $1 \mathrm{ml}$ of $75 \%$ ethanol, and then resuspended in DEPC-water (Mahesh et al. 1999).

\section{Semi-quantitative reverse transcription-PCR (RT-PCR) analysis}

RNA was transcribed into cDNA (cDNA) with reverse transcriptase (Promega Corporation) using random primers (Promega Corporation) in $50 \mathrm{mmol} / \mathrm{l}$ Tris$\mathrm{HCl} ; 50 \mathrm{mmol} / \mathrm{l} \mathrm{KCl} ; 10 \mathrm{mmol} / 1 \mathrm{MgCl}_{2} ; 10 \mathrm{mmol} / \mathrm{l}$ dithiothreitol (DTT); $0.5 \mathrm{mmol} / 1$ spermidine and $1 \mathrm{mmol} / \mathrm{l} \mathrm{dNTPs}$ at $42{ }^{\circ} \mathrm{C}$ for $60 \mathrm{~min}$ (Hsu et al. 2001).

PCR was performed with specific primers for COII, PGC1, mtTFA, glyceraldehydes-3-phosphate dehydrogenase (GAPDH) and 18S. Primers for PGC-1 (5'-TCCTCTGACCC CAGACTCAC- $3^{\prime}$ ) and (5'-TAGAGTCTTGGAGCTCCT $-3^{\prime}$ ) amplify a 442 bp fragment (Portilla et al. 2002) primer for mtTFA (5'-GGGTCTTGTCTGTATTCCGAA-3') and (5'TGAAACGATCCGGAGACATCT- $3^{\prime}$ ) amplify a 633 bp fragment primers for COII (5'-CACCAATGATACTGAAGCTACG-3') and (5'-GTTACTGTTGCTTGATTTAGTCG-3') amplify a $250 \mathrm{bp}$ fragment primers for GAPDH $\left(5^{\prime}\right.$ ACCACAGTCCATGCCATCAC-3 ${ }^{\prime}$ ) and (5'-TCCACCACCCTGTTGCTGTA $-3^{\prime}$ ) amplify a $450 \mathrm{bp}$ fragment; primers for 18S (5'-CCGCAGCTAGGAATAATGGAATAGGAC- $\left.3^{\prime}\right)$ and (5'-ACGACGGTATCTGATCGTCTTCG-3') amplify a $220 \mathrm{bp}$ fragment. The cDNA amplifications were carried out in a $25 \mu \mathrm{l}$ mixture containing $10 \mathrm{mmol} / \mathrm{l}$ Tris$\mathrm{HCl}, 50 \mathrm{mmol} / \mathrm{l} \mathrm{KCl}, 1 \mathrm{mmol} / 1 \mathrm{MgCl}_{2}, 0 \cdot 1 \mathrm{mmol} / 1$ primer, and $1 \mathrm{U}$ Taq DNA polymerase. The reaction profile was as follows. COII: denaturation for 1 min at $94^{\circ} \mathrm{C}$, annealing for 2 min at $59{ }^{\circ} \mathrm{C}$, and extension for $2 \mathrm{~min}$ at $72^{\circ} \mathrm{C}$ running for 28 cycles; PGC-1: denaturation for $1 \mathrm{~min}$ at $94^{\circ} \mathrm{C}$, annealing for 2 min at $63{ }^{\circ} \mathrm{C}$, and extension for 2 min at $72{ }^{\circ} \mathrm{C}$ running for 35 cycles; mtTFA: denaturation for $1 \mathrm{~min}$ at $94^{\circ} \mathrm{C}$, annealing for $2 \mathrm{~min}$ at $58^{\circ} \mathrm{C}$, and extension for $2 \mathrm{~min}$ at $72{ }^{\circ} \mathrm{C}$ running for 28 cycles; GAPDH: denaturation for $1 \mathrm{~min}$ at $94^{\circ} \mathrm{C}$, annealing for $2 \mathrm{~min}$ at $60^{\circ} \mathrm{C}$, and extension for 2 min at $72^{\circ} \mathrm{C}$ running for 25 cycles; 18S: denaturation for $1 \mathrm{~min}$ at $94^{\circ} \mathrm{C}$, annealing for $1 \mathrm{~min}$ at $55^{\circ} \mathrm{C}$, and 


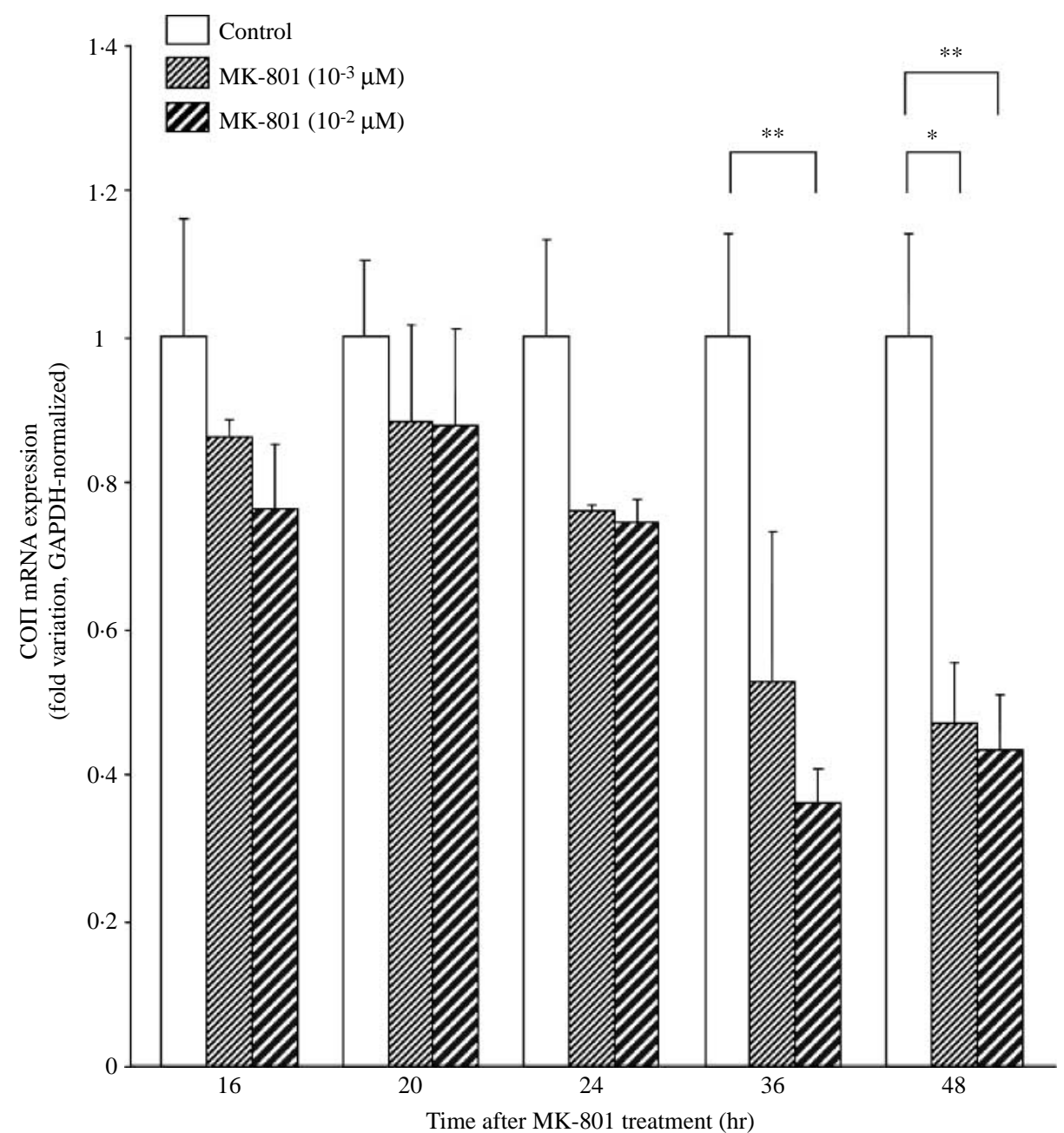

Figure 1 The effects of MK-801 on the expression of cytochrome oxidase subunit II (COII) mRNA in the GT1-7 cells. Cultured cells were maintained for 1 day before treating with MK-801 $\left(0,10^{-3}\right.$ or $10^{-2} \mu \mathrm{M}$ ) for $16,20,24,36$ or $48 \mathrm{~h}$. Expression of mRNA was quantified by real-time PCR. The GAPDH product was used as an internal control. Four samples were analyzed in each group and values represent the means \pm S.E.M. ${ }^{*} P<0.05 ;{ }^{\star \star} P<0.01$.

extension for $1 \mathrm{~min}$ at $72{ }^{\circ} \mathrm{C}$ running for 25 cycles. PCR-amplified DNA fragments were visualized by ethidium bromide staining after agarose gel electrophoresis (Chandrasekaran et al. 1998).

\section{Quantitative real-time PCR}

RNA was transcribed into cDNA (cDNA) with reverse transcriptase (Promega Corporation) using random primers (Promega Corporation) in $50 \mathrm{mmol} / 1$ Tris$\mathrm{HCl} ; 50 \mathrm{mmol} / \mathrm{l} \mathrm{KCl} ; 10 \mathrm{mmol} / 1 \mathrm{MgCl}_{2} ; 10 \mathrm{mmol} / \mathrm{l}$ DTT; $0.5 \mathrm{mmol} / 1$ spermidine and $1 \mathrm{mmol} / 1 \mathrm{dNTPs}$ at $42{ }^{\circ} \mathrm{C}$ for $60 \mathrm{~min}$. Real-time PCR was performed using the SYBR Green method on an ABI PRISM 7900HT Sequence Detection System (Applied Biosystems,
Foster City, CA, USA). The sequences of primers used in this study were designed using the ABI Prism Primer Express Program (Applied Biosystems). PCR was performed using specific primers for COII, PGC-1, mtTFA, and GAPDH. Primers for PGC-1 (5'ACAGTCTCCCCGTGGATGAA- $\left.3^{\prime}\right)$ and $\left(5^{\prime}-\right.$ TCAGTGGTCACGGCTCCAT- $3^{\prime}$ ) primers for mtTFA $\left(5^{\prime}\right.$-CCAAAAAGACCTCGTTCAGCAT- $\left.3^{\prime}\right)$ and $\left(5^{\prime}-\right.$ TTTCCCTGAGCCGAATCATC-3 ${ }^{\prime}$ ) primers for COII $\left(5^{\prime}\right.$-GAGCAGTCCCCTCCCTAGGA- $\left.3^{\prime}\right)$ and $\left(5^{\prime}-\right.$ CCTGGTCGGTTTGATGTTACTGT- $3^{\prime}$ ) primers for GAPDH (5'-ATGTGTCCGTCGTGGATCTGA- $\left.{ }^{\prime}\right)$ and $\left(5^{\prime}\right.$-ATGCCTGCTTCACCACCTTCT- $\left.{ }^{\prime}\right)$. The cDNA amplifications were carried out in a $25 \mu \mathrm{l}$ mixture containing $12.5 \mu \mathrm{l}$ of $2 \times$ SYBR Green PCR Master Mix 


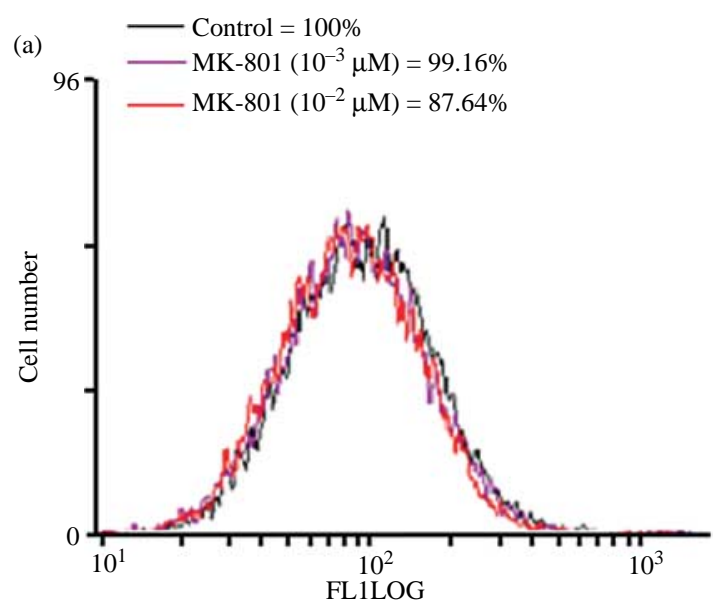

Fluo-3 fluorescence intensity $16 \mathrm{hr}$ exposure to MK-801

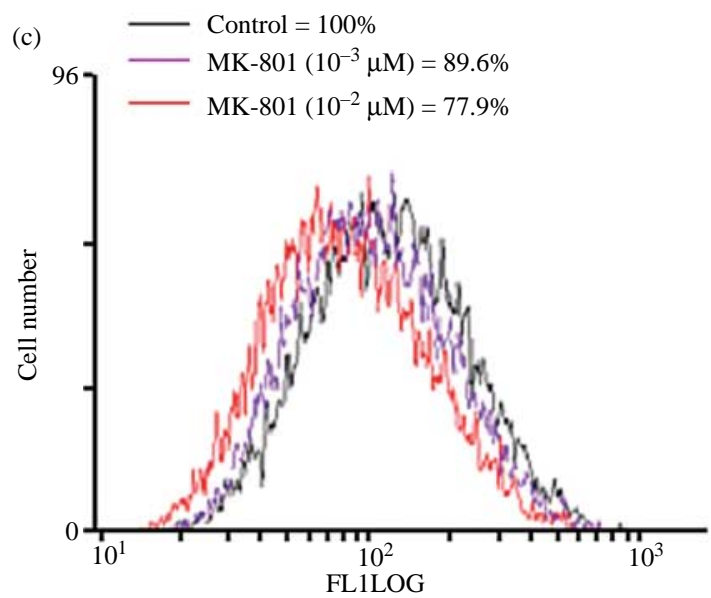

Fluo-3 fluorescence intensity

$24 \mathrm{hr}$ exposure to MK-801

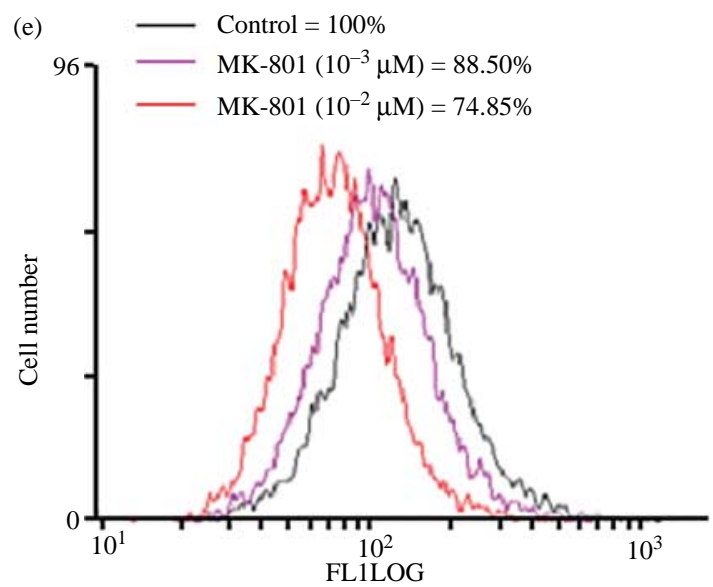

Fluo-3 fluorescence intensity

$48 \mathrm{hr}$ exposure to MK-801

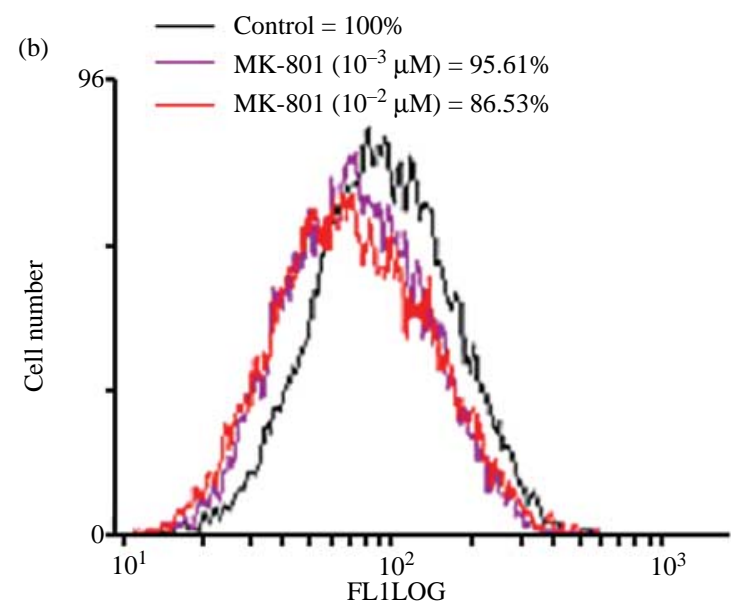

Fluo-3 fluorescence intensity $20 \mathrm{hr}$ exposure to MK-801

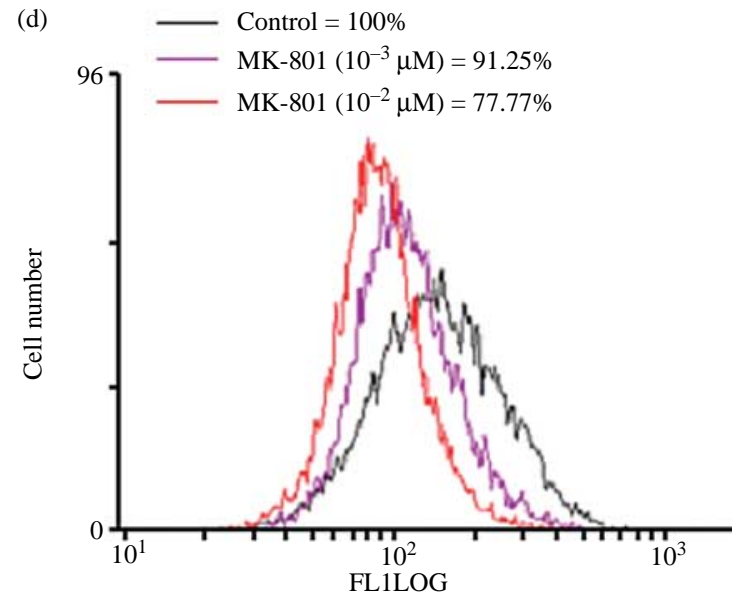

Fluo-3 fluorescence intensity $36 \mathrm{hr}$ exposure to MK-801

(f)

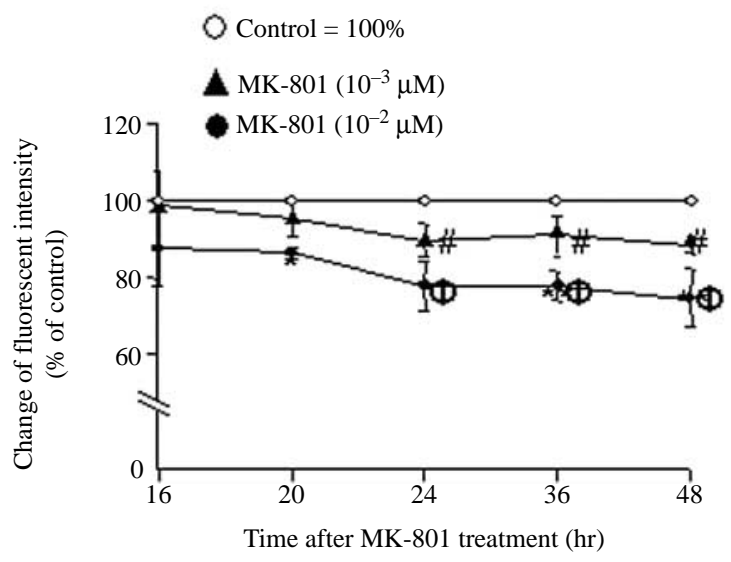

www.endocrinology-journals.org 
(Applied Biosystems), $300 \mathrm{nM}$ primers and $50 \mathrm{ng}$ cDNA. All samples were performed with triplicate and nontemplate control (NTC). GAPDH mRNA was used as the internal control. Analysis was performed using SDS version 2.1 software (Applied Biosystems). The comparative $C_{\mathrm{T}}$ method was used for quantification of gene expression.

\section{Western blot analysis of PGC-1}

The cells were homogenized in lysis buffer $(50 \mathrm{mmol} / \mathrm{l}$ Tris-base, $150 \mathrm{mmol} / \mathrm{l}$ Nacl, $5 \mathrm{mmol} / 1$ EDTA, $50 \mathrm{mmol} / 1 \mathrm{NaF}, 0 \cdot 1 \mathrm{mmol} / 1 \mathrm{Na}_{3} V_{4}, 1 \%$ Triton X-100, $1 \mathrm{mmol} / \mathrm{l}$ AEBSF and $10 \mu \mathrm{g} / \mathrm{ml}$ leupeptin, $\mathrm{pH} 7 \cdot 4$ ) and incubated at $4{ }^{\circ} \mathrm{C}$ for $10 \mathrm{~min}$. Supernatant containing the total protein was collected by centrifuging for $15 \mathrm{~min}$ at $22000 \mathrm{~g}$. The protein concentrations were estimated using the Bio-Rad protein microassay procedure (Bradford 1976). Samples were heated for $5 \mathrm{~min}$ in boiling water before loading. Equal amounts of protein $(20 \mu \mathrm{g})$ were separated by $10 \%$ SDS-PAGE, transferred onto polyvinylidene difluoride membrane by electroblotting for $1 \mathrm{~h}(100 \mathrm{~V})$, and then blocked with the Tween-Tris buffer saline solution (t-TBS; $20 \mathrm{mmol} / 1$ Trisbase, $0.44 \mathrm{mmol} / 1 \mathrm{NaCl}, 0 \cdot 1 \%$ Tween $20, \mathrm{pH} 7 \cdot 6$ ) containing $5 \%$ nonfat dry milk and $0.1 \%$ Tween 20 at $4{ }^{\circ} \mathrm{C}$ for overnight. The blot was then incubated with polyclonal PGC-1 antibody (Santa Cruz Biotechnology Inc., Santa Cruz, CA, USA) at 1:200 dilution in t-TBS containing $5 \%$ nonfat dry milk and $0 \cdot 1 \%$ Tween 20 for $1 \mathrm{~h}$ (Baar et al. 2002). Subsequently, membranes were incubated for $1 \mathrm{~h}$ with the secondary antibody (1:5000) at room temperature, and then washed for $1 \mathrm{~h}$ with the t-TBS. The membrane was also probed with $\beta$-actin antibody to correct for difference in protein loading. Immunoreactive protein was visualized by enhanced chemiluminescence (Amersham) according to the manufacturer's specifications (Siegel et al. 1994, Yang et al. 2003).

\section{Extraction of nuclear protein and electrophoretic mobility shift assay (EMSA)}

Cells were plated at a density of $6 \times 10^{5}$ cells $/ \mathrm{cm}^{3}$ in a $10 \mathrm{~cm}$ dish. The culture medium was removed when the cells reached $90 \%$ confluence and $1 \mathrm{ml}$ PBS was added to cover the cells. The cells from eight dishes were scraped into conical centrifuge tube and centrifuged for $5 \mathrm{~min}$ at
1500 r.p.m. The packed cells were resuspended in five volume of hypotonic buffer ( $10 \mathrm{nmol} / \mathrm{l}$ HEPES, $\mathrm{pH} 7 \cdot 9$, $10 \mathrm{mmol} / 1 \mathrm{KCl}, 1.5 \mathrm{mmol} / 1 \mathrm{MgCl}_{2}, 0.5 \mathrm{mmol} / 1 \mathrm{DTT}$, $1 \mathrm{mmol} / \mathrm{l}$ AEBSF and $10 \mu \mathrm{g} / \mathrm{ml}$ leupeptin), centrifuged for $5 \mathrm{~min}$ at 1500 r.p.m, and the supernatant was discarded. The pellet was resuspended in a hypotonic buffer and allowed swelling for $10 \mathrm{~min}$ on the ice. The nuclei were collected by centrifuging for $15 \mathrm{~min}$ at 4000 r.p.m. A volume of high-salt buffer $(20 \mathrm{mmol} / \mathrm{l}$ HEPES, pH 7.9, $0.42 \mathrm{~mol} / \mathrm{l} \mathrm{NaCl}, 20 \%$ glycerol, $1 \mathrm{mmol} / \mathrm{l} \mathrm{EDTA,} 1 \mathrm{mmol} / \mathrm{l}$ DTT, $1 \mathrm{mmol} / 1$ 4-(2-aminoethyl) benzenesulfonyl flouride (AEBSF) and $10 \mu \mathrm{g} / \mathrm{ml}$ leupeptin) equal to nuclear packed volume was added and stirred at $4{ }^{\circ} \mathrm{C}$ for $30 \mathrm{~min}$. The nuclear extracts were centrifuged for $15 \mathrm{~min}$ at 14000 r.p.m and the supernatant was dialyzed using a $100 \times$ volume of dialysis buffer for $1 \mathrm{~h}$. For determination of protein-DNA interactions, the double-stranded oligonucleotide containing a functional NRF-2 consensus binding site in the mtTFA promoter (the recognition sequence for NRF-2 is oligo $5^{\prime}$ CTGCAGACCGGAAGTCTGGG-3' (Choi et al. 2002) and mutant NRF-2 consensus binding sequence is $5^{\prime}$-CCCAGACTGAAATGATGCAG-3') were purchased from Promega and end-labeled with $\gamma^{32} \mathrm{P}$-ATP according to the manufacturer's recommendation. The binding reactions of NRF-2 or mutant NRF-2 to mtTFA promoter were performed in a final volume of $20 \mu \mathrm{l}$ mixtures containing buffer $(10 \mathrm{mmol} / 1$ HEPES, pH7 $5,1 \mu \mathrm{g}$ poly $(\mathrm{dI}-\mathrm{dC})$, $0.1 \mathrm{~mol} / 1 \mathrm{NaCl}, 0.8 \mathrm{mmol} / 1 \mathrm{EDTA}, 1 \mathrm{mmol} / 1 \mathrm{DTT}$, $0.05 \% \mathrm{NP}-40$, and $4 \%$ glycerol), $10 \mu \mathrm{g}$ nuclear proteins, and 100000 c.p.m of the radiolabeled probe. The mixtures were incubated at room temperature for 20 min. For competition assay, a 50-fold excess amount of cold NRF-2 or mutant NRF-2 oligonucleotide was preincubated with nuclear proteins for $45 \mathrm{~min}$ before the addition of labeled probe. The DNA-protein complexes were resolved on $5 \%$ nondenaturing polyacrylamide gel in $0.5 \times$ TGE (Tris base, glycine, EDTA) buffer. The gel was dried and exposed to X-ray film overnight at $-70^{\circ} \mathrm{C}$. (Kanke et al. 1998, Kain et al. 2000, Choi et al. 2002, Dong et al. 2002).

\section{Terminal deoxynucleotidyl transferase (TdT)- mediated dUTP-biotin nick-end labeling (TUNEL stain) for apoptosis detection}

For TUNEL assay, a TdT FragEL DNA Fragmentation Detection kit (Oncogene, Cambridge, MA, USA) was

Figure 2 MK-801 dose dependently decreases intracellular $\mathrm{Ca}^{2+}$ concentrations in GT1-7 cells. Intracellular calcium concentrations in the GT1-7 cells were measured using Fluo-3 green fluorescence following treatment with MK-801 $\left(0,10^{-3}\right.$, or $\left.10^{-2} \mu \mathrm{M}\right)$ for (a) 16 , (b) 20 , (c) 24 , (d) 36 or (e) $48 \mathrm{~h}$. These results demonstrate that viable single cell-suspensions of GT1-7 can be obtained for intracellular Ca ${ }^{2+}$ analysis using flow cytometry. (f) Quantitative results $(n=3)$. Values represent means \pm s.E.M. Comparisons were subjected to ANOVA followed by Fisher's least significant difference test. Significance was accepted at $P<0 \cdot 05 .{ }^{*} P<0 \cdot 05,{ }^{* \star} P<0 \cdot 01, \mathrm{MK}-801\left(10^{-2} \mu \mathrm{M}\right)$ versus control; ${ }^{\#} P<0.05$, MK-801 $\left(10^{-3} \mu \mathrm{M}\right)$ versus control; ${ }^{\Phi} P<0 \cdot 05, \mathrm{MK}-801\left(10^{-3} \mu \mathrm{M}\right)$ versus MK-801 $\left(10^{-2} \mu \mathrm{M}\right)$. 


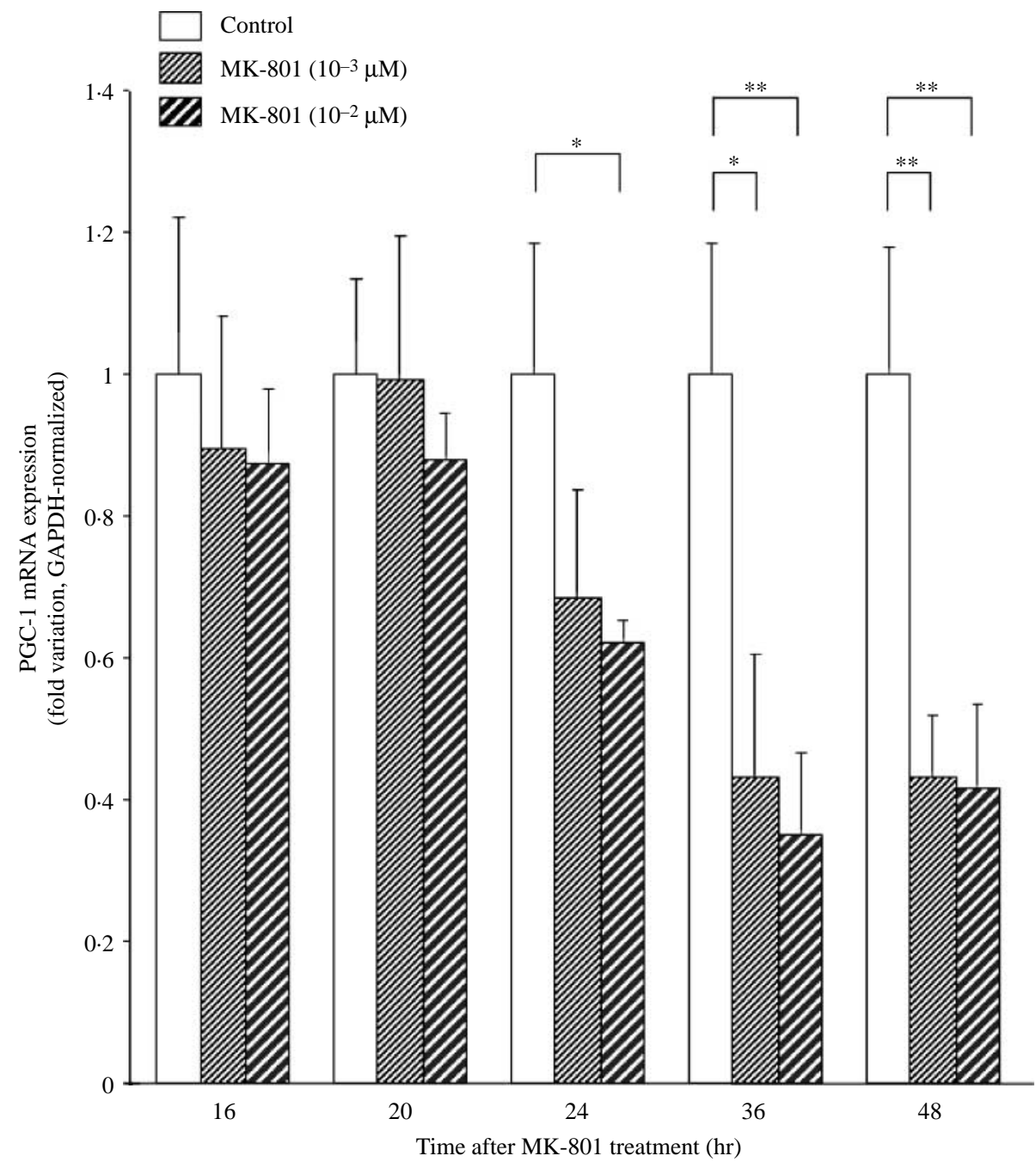

Figure 3 Effects of MK-801 on the expression of PGC-1 mRNA in GT1-7 cells. Cultured cells were maintained for 1 day before treating with MK-801 $\left(0,10^{-3}\right.$ or $\left.10^{-2} \mu \mathrm{M}\right)$ for $16,20,24,36$, or $48 \mathrm{~h}$. The mRNA levels were quantified by real-time PCR. The GAPDH mRNA was used as an internal control. Four samples were analyzed in each group and values represent the means \pm S.E.M. ${ }^{\star} P<0.05 ;{ }^{\star \star} P<0.01$.

used according to the manufacturer's instructions. The cells were plated at a density of $1 \times 10^{5}$ on a six-well plate and incubated at $37^{\circ} \mathrm{C}$ for 1 day. After treating with or without MK-801 $\left(10^{-2}\right.$ or $\left.10^{-3} \mu \mathrm{M}\right)$ for $16,20,24,36$ or $48 \mathrm{~h}$, the cells (including the floating cells) were harvested, fixed in $4 \%$ paraformaldehyde, and then centrifuged at 1500 r.p.m for 5 min. Pellets were re-suspended with $80 \%$ ethanol. The cells at a concentration of $2 \times 10^{5}$ cells $/ \mathrm{cm}^{3}$ were fixed onto glass slides using a Cytospin at 2000 r.p.m for $5 \mathrm{~min}$, pretreated with proteinase $\mathrm{K}$ and $\mathrm{H}_{2} \mathrm{O}_{2}$, and then incubated in equilibration buffer followed by workingstrength TdT enzyme (TdT labeled dUTP nucleotides to free $3^{\prime}-\mathrm{OH}$ DNA termini) at $37^{\circ} \mathrm{C}$ for $1.5 \mathrm{~h}$. The cell slides were incubated in a stop/wash buffer for $15 \mathrm{~min}$, stained with 3,3'-diaminobenzidine (DAB) solution, and then counterstained with methyl green. The incidence of apoptosis was derived from the quotient of apoptotic nucleus number divided by the sum of total neuron numbers in each slides (Hsu et al. 2001).

\section{Statistical analysis}

All data were expressed as the mean value \pm s.E.M. Comparisons were subjected to ANOVA followed by Scheffe's least significant difference test. $P<0.05$ was considered as significant difference. 

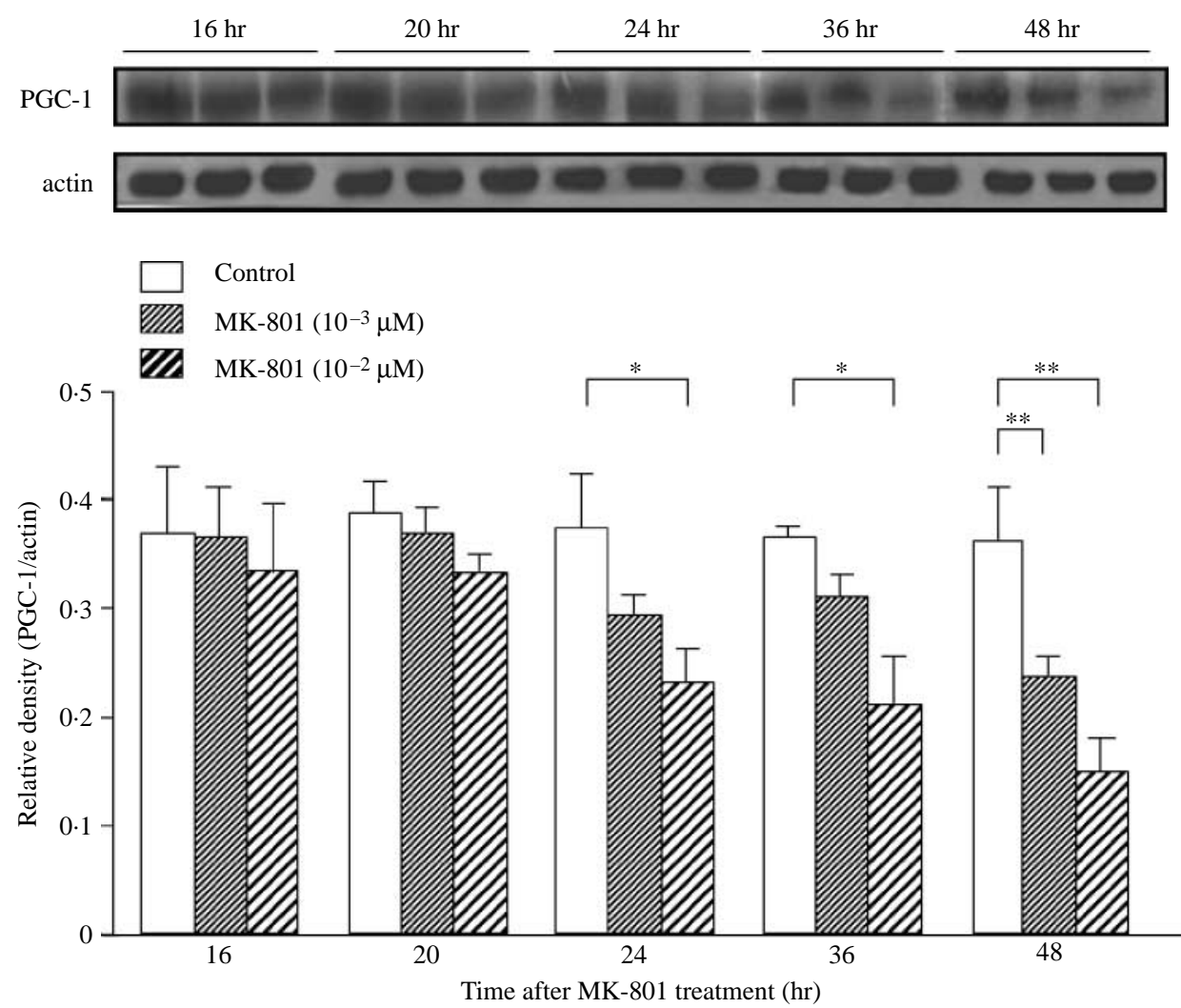

Figure 4 Effect of MK-801 on the protein levels of PGC-1 in GT1-7 cells. Cultured cells were maintained for 1 day before treating with MK-801 $\left(0,10^{-3}\right.$, or $\left.10^{-2} \mu \mathrm{M}\right)$ for $16,20,24,36$, or $48 \mathrm{~h}$. Molecular weight of PGC-1 is $86 \mathrm{kDa}$. $\beta$-Actin (43 kDa) was used as an internal standard. Four samples were analyzed in each group and values represent the means \pm S.E.M. ${ }^{*} P<0.05$.

\section{Results}

\section{Effect of MK-801 on the expression of COII mRNA}

Initially, we examined whether MK-801 treatment could affect the expression of COII gene in GT1-7 cells. The levels of COII mRNA were quantified by real-time PCR. As illustrated in Fig. 1, treatment of GT1-7 with MK-801 $\left(10^{-2}\right.$ or $\left.10^{-3} \mu \mathrm{M}\right)$ for 36 or $48 \mathrm{~h}$ resulted in a decrease of COII mRNA level $(P<0 \cdot 05)$. No significant change of the level of COII mRNA was observed before $36 \mathrm{~h}$ treatment with MK-801.

\section{Effect of MK-801 on intracellular free calcium levels in GT1-7 cells}

To examine whether the change of $\left[\mathrm{Ca}^{2+}\right]_{\mathrm{i}}$ was involved in the MK-801-induced increase of COII in GT1-7 cells, we conducted flow cytometric analysis to determine intracellular free calcium concentrations using Fluo-3 AM as the fluoro probe. As illustrated in Fig. $2 a-e$, a significant decrease of $\left[\mathrm{Ca}^{2+}\right]_{\mathrm{i}}$ induced by MK-801 $\left(10^{-2}\right.$ and $\left.10^{-3} \mu \mathrm{M}\right)$ was observed at $24 \mathrm{~h}$ after treatment. This decrease was in a time- and dosedependent manner (Fig. 2f).

\section{MK-801 decreases the expression of PGC-1 in GT1-7 cells}

The expression of PGC-1, which regulates the expression of NRF-2 and subsequent mtTFA and COII, could be affected by intracellular free calcium concentrations. To examine the effect of MK-801 on the PGC-1 gene expression in GT1-7 cells, we conducted real-time PCR and western blot analyses to measure the levels of PGC-1 mRNA and protein respectively. The results showed that both the RT-PCR product of PGC-1 (Fig. 3) and protein level of PGC-1 (Fig. 4) in GT1-7 cells were significantly decreased after $24 \mathrm{~h}$ treatment with MK-801. These inhibitions were in a dose- and time-dependent manner.

\section{Effect of MK-801 on the DNA-binding activity of NRF-2 and the levels of mtTFA mRNA}

It has been shown that PGC-1 could induce the expression of NRF-2, which regulates multiple target 
$\begin{array}{llllllllllll}1 & 2 & 3 & 4 & 5 & 6 & 7 & 8 & 9 & 10\end{array}$
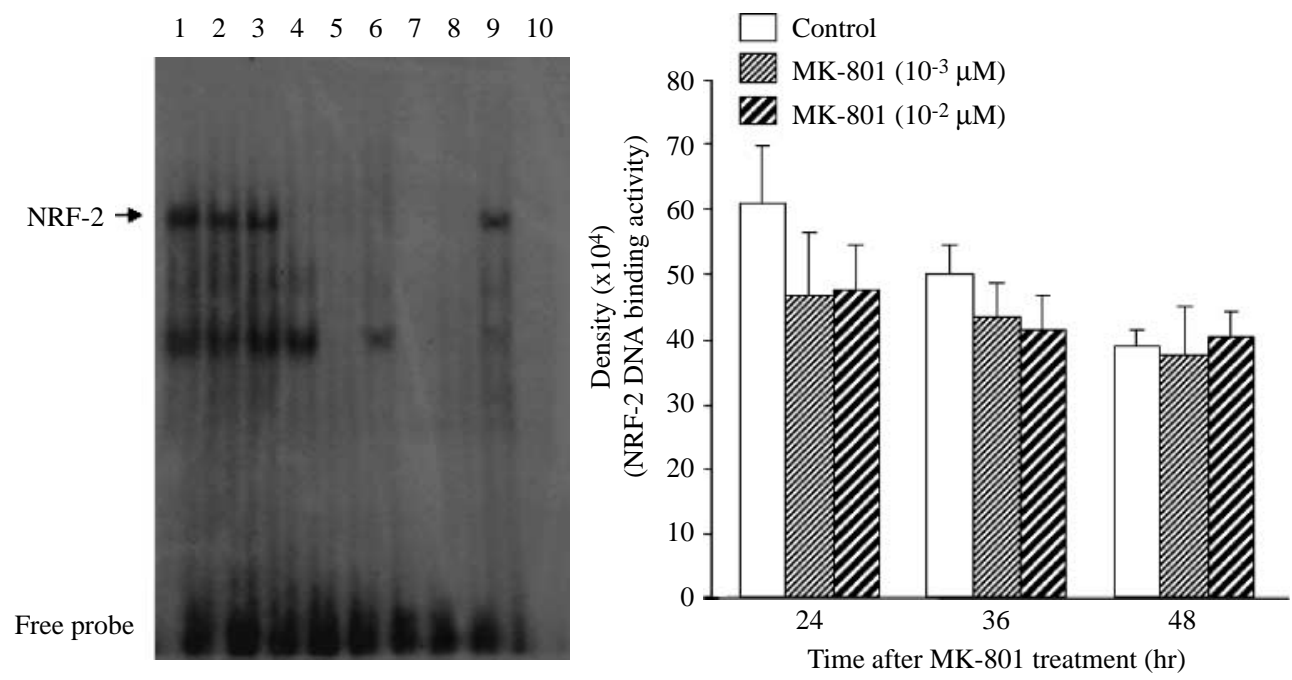

Figure 5 Effect of MK-801 on the DNA-binding activity of NRF-2 in GT1-7 cells. 1. Left panel was treated with MK-801 for $36 \mathrm{~h}$, a representative data of EMSA. Cultured cells were homogenized with hypotonic buffer and high-salt buffer. Lane 1: control, NRF-2 probe; lane 2: $10^{-3} \mu \mathrm{M}$ MK-801, NRF-2 probe; lane 3 : $10^{-2} \mu \mathrm{M}$ MK-801, NRF-2 probe; lane 4: control, mutanted NRF-2 probe; lane 5: control, competition with $50 \times$ specific mutant NRF-2 consensus sequence, mutant NRF-2 oligonucleotide $\left(5^{\prime}-\right.$ CTG CAT CAT TTC AGT CTG GG $-3^{\prime}$ ) was preincubated with nuclear proteins for $45 \mathrm{~min}$ before the addition of labeled probe; lane 6: control, mutanted NRF-2 consensus sequence, nonspecific competition with $5 \mathrm{pmol} / \mu \mathrm{l}$ p53 consensus sequence; lane 7: mutanted NRF-2 consensus sequence probe only; lane 8: control, competition with $50 \times$ specific NRF-2 consensus sequence, NRF-2 oligonucleotide (5'-CTG CAG ACC GGA AGT CTG GG-3') was preincubated with nuclear proteins for $45 \mathrm{~min}$ before the addition of labeled probe; lane 9: control, NRF-2 consensus sequence, nonspecific competition with $5 \mathrm{pmol} / \mu \mathrm{l}$ p53 consensus sequence; lane 10: NRF-2 consensus sequence probe only. Right panel: quantitative results of EMSA. Eight samples were analyzed in each group, and values represent the means \pm S.E.M.

genes including mtTFA, which could activate COII expression. Accordingly, we examined the effect of MK801 on binding activity of NRF-2 on mtTFA in GT1-7 cells by conducting the EMSA. Surprisingly, no significant difference of mtTFA/NRF-2 binding was observed between MK-801 treated and control cells as shown in Fig. 5. In specific competition analysis, binding of NRF-2 was significantly competed by 50 -fold unlabeled NRF-2 oligonucleotide 5'-CTG CAG ACC GGA AGT CTG GG-3' . In nonspecific competition analysis, unlabeled p53 did not compete with labeled NRF-2 oligonucleotide. Since the binding between mtTFA DNA and NRF-2 was not affected by MK-801 treatment, we further examined whether the levels of mtTFA and mtTFB1M and mtTFB2M were affected by MK-801 treatment or not. The mtTFA (Fig. 6), TFB1M (Fig. 7), and TFB2M (Fig. 8) mRNA levels were significantly decreased at 24,48 , and $48 \mathrm{~h}$ after MK-801 treatment respectively.

\section{Neuronal apoptosis induced by blocking of the NMDA receptor}

To study whether blocking of the NMDA receptor could induce apoptosis in GT1-7 cells, the TUNEL staining assay was performed in the cultured GT1-7 cells treated with or without MK-801. As shown in Fig. 9, treatment of
GT1-7 cells with MK-801 $\left(10^{-2}\right.$ or $\left.10^{-3} \mu \mathrm{M}\right)$ for 36 or $48 \mathrm{~h}$ significantly increased the population of apoptotic cells when compared with the cells without MK-801 treatment $(P<0 \cdot 01)$.

\section{Discussion}

Previously, we have demonstrated that the apoptotic incidence of neurons in SDN-POA of male rats is significantly increased when NMDA receptor is blocked by MK-801 (Hsu et al. 2001) and the physiological activation of NMDA receptor may protect against neuronal death by transcriptional increase of some survival-related genes, including COII, in SDN-POA during sexual development (Hsu et al. 2005). In this study, we attempted to map the signaling pathway of NMDA receptor-mediated neuronal survival in the GT17 cell lines, which were derived from hypothalamic GnRH neurons and expressed NMDA receptor as well as mitochondrial COII genes, by comparing the time course of intracellular events, which have been suggested to be involved in the neuronal apoptosis, induced by blocking the activation of NMDA receptor. The results from the present study suggest that blocking of the NMDA receptor causes a decrease of $\left[\mathrm{Ca}^{2+}\right]_{i}$, which in turn may inhibit the expressions of PGC-1, 


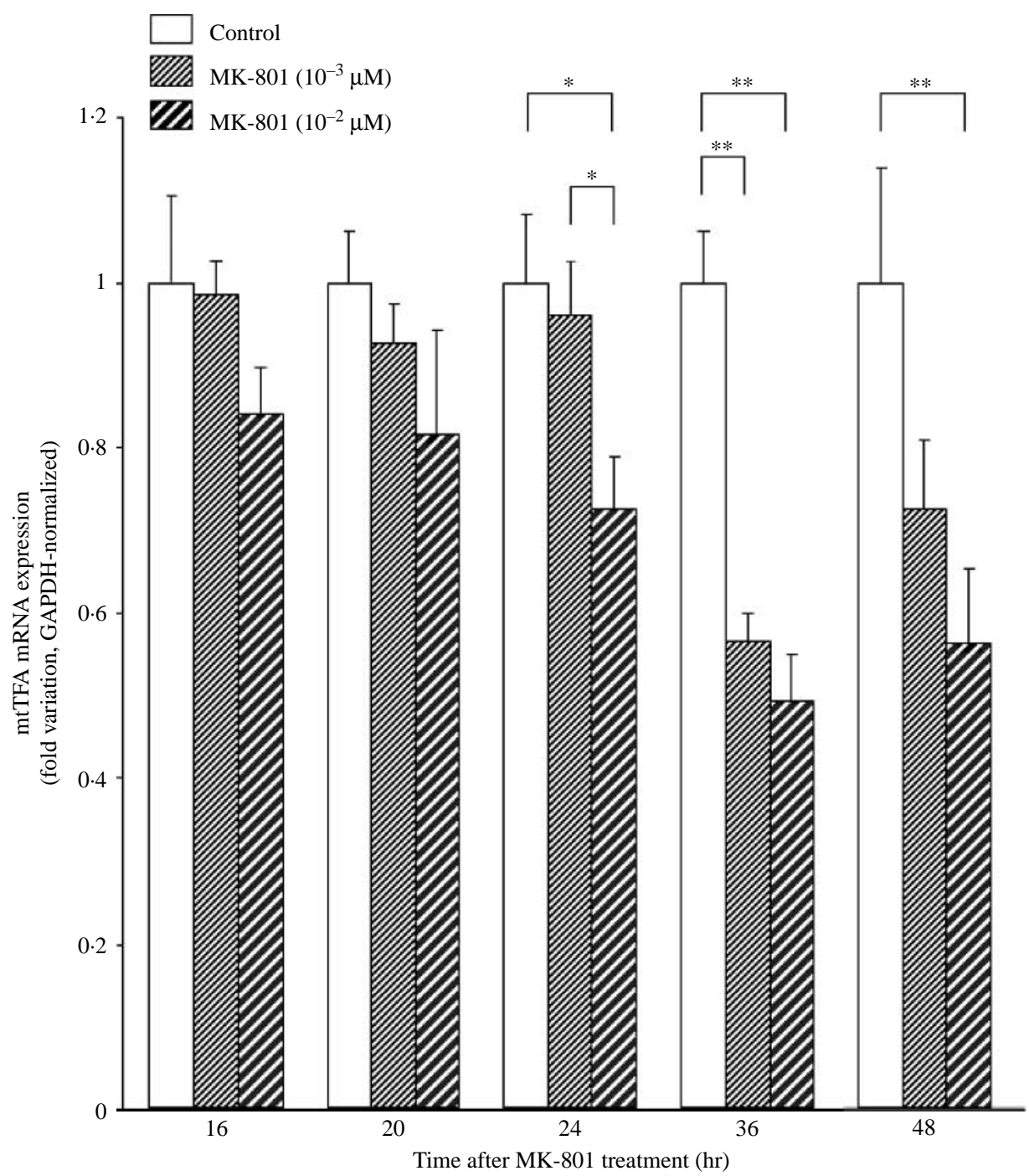

Figure 6 Effect of MK-801 on the expression of mitochondrial transcription factor A (mtTFA) mRNA in GT1-7 cells. Cultured cells were maintained for 1 day before treating with MK-801 $\left(0,10^{-3}\right.$, or $\left.10^{-2} \mu \mathrm{M}\right)$ for $16,20,24,36$, or $48 \mathrm{~h}$. Expression of mRNA was quantified by real-time PCR. The GAPDH mRNA was used as an internal control. Four samples were analyzed in each group and values represent the means \pm S.E.M. ${ }^{*} P<0.05 ;{ }^{* \star} P<0.01$.

NRF-2 and COII gene, and finally leads to the occurrence of apoptosis in the GT1-7 cell line.

It is well accepted that activation of the neuronal NMDA receptor results in elevation of intracellular calcium and phosphorylation of CaMKIV (Yano et al. 1998). Activation of CaMK could induce expression of PGC-1 (Wu et al. 2002). In the present study, we observed a decrease in the $\left[\mathrm{Ca}^{2+}\right]_{\mathrm{i}}$ and the occurrence of neuronal apoptosis in the MK-801 treated GT1-7 cell line. These findings are consistent with previous reports suggesting that intracellular $\mathrm{Ca}^{2+}$ deficiency plays a causative role in MK-801/6-cyano-7-nitroquinoxaline2,3-dione (CNQX)-induced activation of caspase-3 and neuronal apoptosis (Yoon et al. 2003). By comparing the time course of intracellular events induced by MK801 treatment, we found that a decrease of $\left[\mathrm{Ca}^{2+}\right]_{\mathrm{i}}$ began at $20 \mathrm{~h}$ after MK-801 (Fig. 1), whereas the levels of PGC-1 mRNA and protein began to decline at $24 \mathrm{~h}$ (Figs 3 and 4), suggesting that declination of $\left[\mathrm{Ca}^{2+}\right]_{\mathrm{i}}$ may be a cause of the MK-801-induced suppression of PGC-1 expression.

It has been shown that PGC-1 could induce the expression of NRF-2, which regulates multiple target genes including mtTFA and TFBMs (Gleyzer et al. 2005). The mtTFs usually translocate into mitochondria and directly activate the transcription and replication of mtDNA (mitochondrial DNA) such as COII. Since it has been shown that the transcription of COII is 


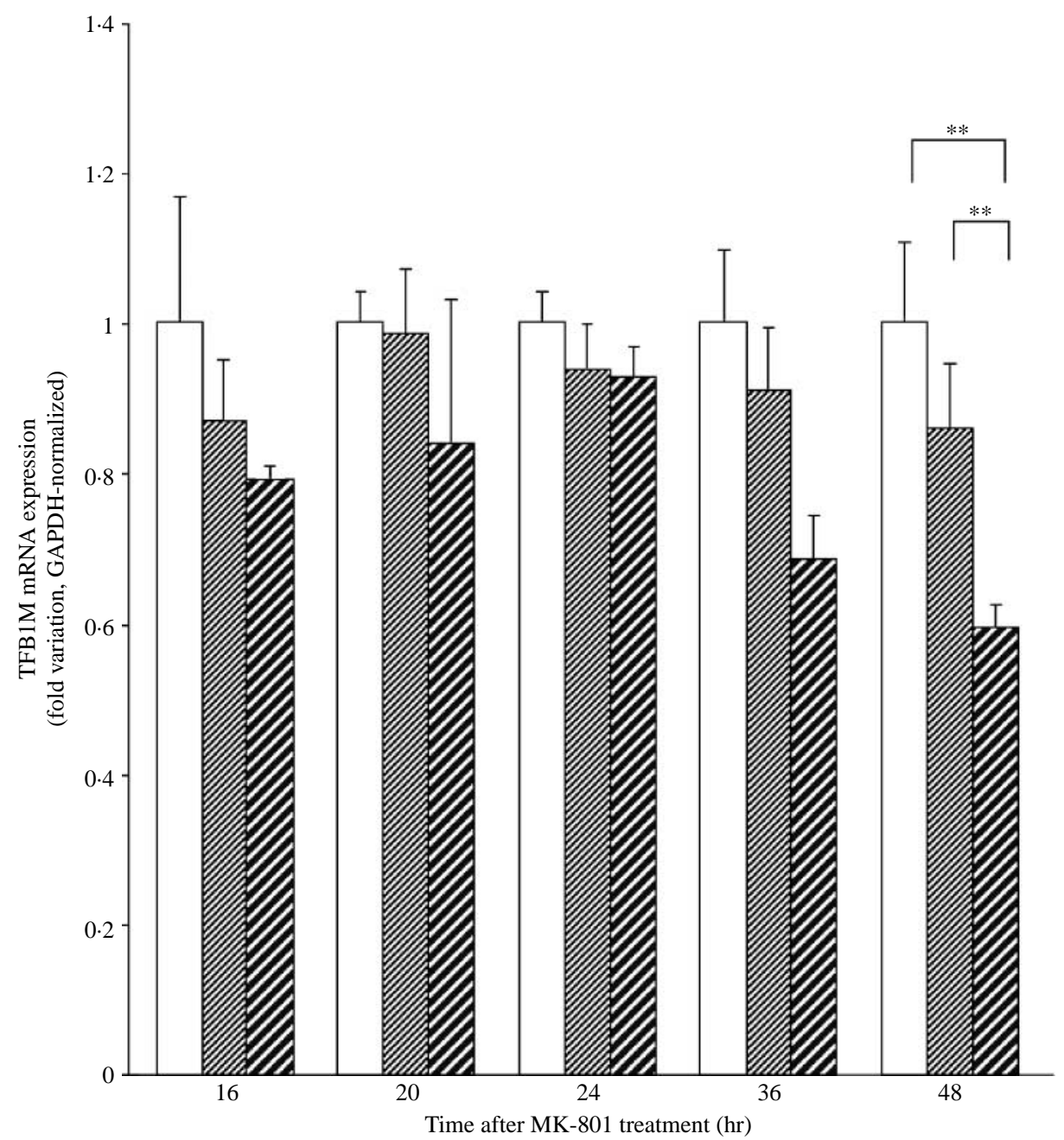

Figure 7 Effect of MK-801 on the expression of mitochondrial transcription factor B1M (TFB1M) mRNA in GT1-7 cells. Cultured cells were maintained for 1 day before treating with MK-801 $\left(0,10^{-3}\right.$, or $10^{-2} \mu \mathrm{M}$ ) for $16,20,24,36$, or $48 \mathrm{~h}$. Expression of mRNA was quantified by real-time PCR. The GAPDH mRNA was used as an internal control. Four samples were analyzed in each group and values represent the means \pm S.E.M. ${ }^{* \star} P<0 \cdot 01$.

activated by mtTFA, Tfam (Dong et al. 2002, Vijayasarathy et al. 2003), it is likely that a decrease in PGC-1 expression would lead to a decrease of COII expression in GT1-7 cells. In the present study, a decrease of COII mRNA level was not observed until $36 \mathrm{~h}$ after MK-801 treatment (Fig. 7), suggesting that COII might be in the downstream of PGC-1, which started to decline at $24 \mathrm{~h}$ after MK-801 treatment.

Previously, it has been indicated that the COII activity and mRNA levels are highly regulated and correlated closely with neuronal activity (Wong-Riley 1989, Capaldi 1990a, Zhang \& Wong-Riley 2000). It was also reported that reduction of hippocampal oxidative metabolism in Alzheimer disease is directly associated with a downregulation of COII mRNA (Chandrasekaran et al. 1998). Moreover, it has been suggested that ATP depletion caused by decreased COII expression might play a significant role in the hypoxia-induced apoptotic cell death (Bae et al. 1998). Administration of ionotropic glutamate receptor antagonists (MK-801/CNQX) induces neuronal apoptosis in vivo and in vitro through activations of caspase- 9 and caspase- 3 , that is preceded by release of mitochondrial cytochrome $c$ and translocation of Bax into mitochondria (Yoon et al. 2003). In the present study, we demonstrated that treatment with MK801 decreased the COII levels and increased the number of TUNEL positive cells in GT1-7 cells at both 36 and $48 \mathrm{~h}$ after MK-801 treatment. Particularly, a prominent increase of apoptotic cells occurred at $48 \mathrm{~h}$ after MK801 treatment, suggesting that the decreased COII expression might account for, at least in part, the MK801-induced apoptosis in GT1-7 cells. 


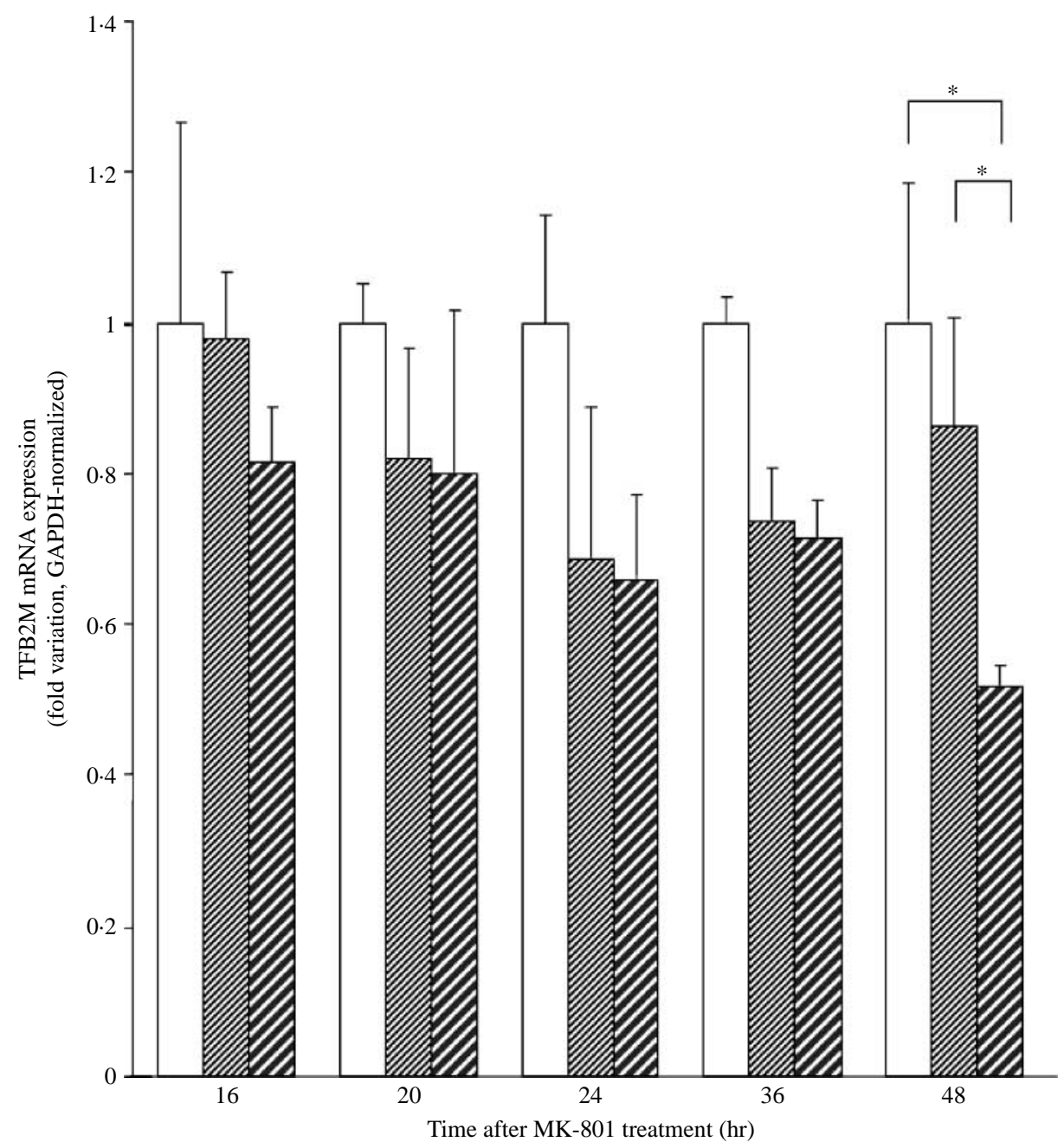

Figure 8 Effect of MK-801 on the expression of transcription factor B2M (TFB2M) mRNA in GT1-7 cells. Cultured cells were maintained for 1 day before treating with MK-801 $\left(0,10^{-3}\right.$, or $\left.10^{-2} \mu \mathrm{M}\right)$ for $16,20,24,36$, or $48 \mathrm{hr}$. Expression of mRNA was quantified by real-time PCR. The GAPDH mRNA was used as an internal control. Four samples were analyzed in each group and values represent the means \pm S.E.M. ${ }^{\star} P<0.05$.

Mitochondrial DNA (mtDNA) transcription is initiated bidirectionally from closely spaced promoters, heavy strand promoters and light strand promoters, within the D-loop regulatory and requires mitochondrial RNA polymerase and mtTFA (Gleyzer et al. 2005). The mtDNA transcription can also be enhanced by mitochondrial transcription-specific factors (TFB1M and TFB2M; Gleyzer et al. 2005). Besides, the high-mobility group (HMG-box) domains of mtTFA proteins are capable of inducing a conformational change in promoter-containing DNA, suggesting that promoter conformation may play an important role in transcription initiation (Tracy \& Stern 1995). Our data suggest that changes of both nuclear and mitochondrial gene expression might be involved in the occurrence of apoptosis induced by blocking of the NMDA receptor. Previous studies indicated that the transcription of COII, a mitochondrial DNA-encoded gene, could be activated by mtTFA, Tfam (Dong et al. 2002, Vijayasarathy et al. 2003). Accordingly, we examined whether mtTFA is involved in the COII expression induced by blocking of the NMDA receptor. Our data indicated that the mtTFA mRNA levels began to decrease at $24 \mathrm{~h}$ after MK-801 treatment (Fig. 6). The mRNA levels of TFB1M and TFB2M, on the other hand, were not decreased until $48 \mathrm{~h}$ after MK-801 treatment (Figs 7 and 8). Surprisingly, the EMSA assay showed that the NRF-2/mtTFA DNA-binding activity between MK-801 treated and control cells is not significantly different 
(a)

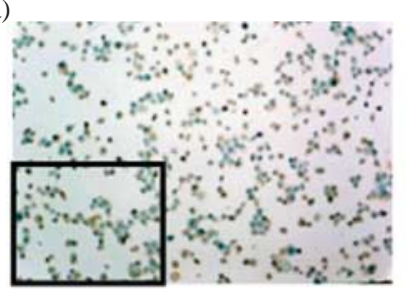

(d)

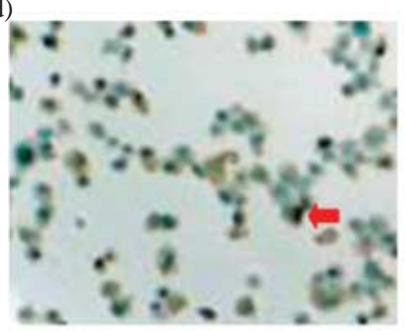

Control (b)

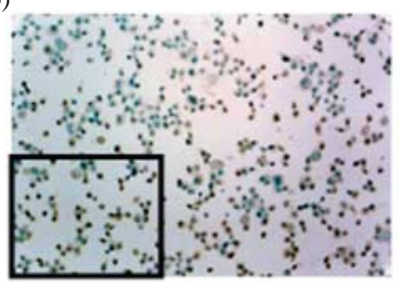

(e)

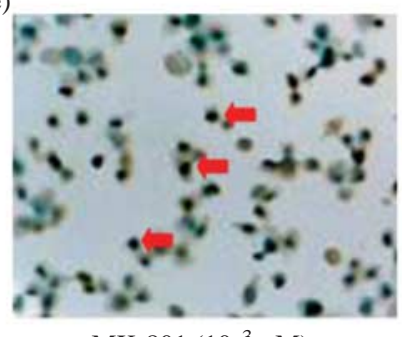

MK-801 $\left(10^{-3} \mu \mathrm{M}\right)$ (c)

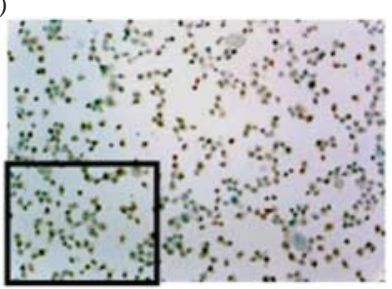

(f)

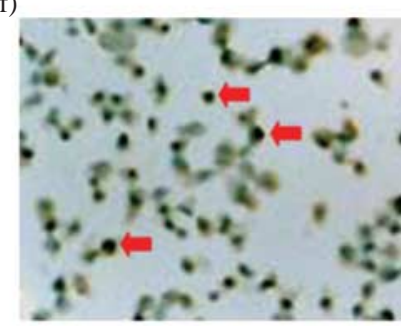

MK-801 $\left(10^{-2} \mu \mathrm{M}\right)$

(g)

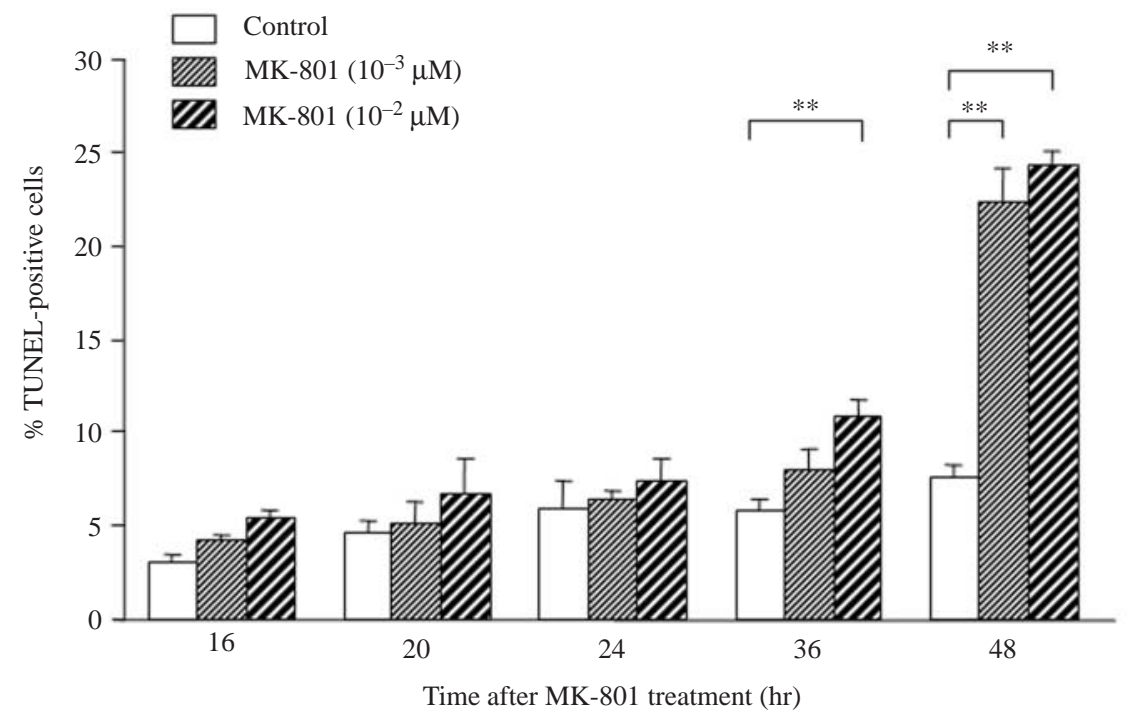

Figure 9 Induction of neuronal apoptosis in GT1-7 cells by MK-801. Cultured cells were maintained for 1 day before treating with MK-801 $\left(0,10^{-3}\right.$, or $\left.10^{-2} \mu \mathrm{M}\right)$ for $16,20,24,36$, or $48 \mathrm{~h}$. (a-c) a representative TUNEL staining after the cells treated for $48 \mathrm{~h}$ with (a) control, (b) $10^{-3} \mu \mathrm{M}$ MK-801 or (c) $10^{-2} \mu \mathrm{M}$ MK-801 respectively. MK-801 dose dependently increased the TUNEL positive cells. $(d-f)$ the insets of $(a-c)$ with a larger magnification. Red arrows indicated representative apoptotic cells. (g) Quantitative results of neuronal apoptosis identified by TUNEL staining. Each slide containing $2 \times 10^{5}$ cells was counted five views. Four samples were analyzed in each group and values represent the means \pm S.E.M. ${ }^{*} P<0.01$.

(Fig. 5). These data suggest that the decreases of mtTFA, TFB1, and TFB2 might be involved in the occurrence of apoptosis induced by MK- 801 .

Recent studies have shown that brain mitochondria undergo swelling and release proteins located in the matrix or the inter-membrane space when exposed to calcium at a concentration of $25 \mu \mathrm{M}$ (Kristal \& Dubinsky 1997). NMDA receptor agonist causes cytochrome $c$ release and procaspase- 3 expression and results in harmful $\mathrm{Ca}^{2+}$ overloading of transient global ischemia (Zhang et al. 2002). Therefore, the NMDA antagonist, MK-801, has been suggested to act as a therapeutic agent to protect neuron against excitotoxicity and $\mathrm{Ca}^{2+}$ overload in vivo (Schulz et al. 1996). Although the proposed signaling pathway involved in the MK-801-induced neuronal apoptosis 
needs to be confirmed by showing some direct evidence, our results from the present study suggest that therapeutic potential of MK-801 might be compromised by its proapoptotic effects on central neurons.

\section{Acknowledgements}

This work was supported by research grants from the National Science Council of Taiwan (NSC 93-12320B-037-003 and NSC-94-2320-B-037-003 to C H and NSC94-2320-B-038-005 to T-Y L). The authors declare that there is no conflict of interest that would prejudice the impartiality of this scientific work.

\section{References}

Baar K, Wende AR, Jones TE, Marison M, Nolte LA, Chen M, Kelly DP \& Holloszy JO 2002 Adaptations of skeletal muscle to exercise: rapid increase in the transcriptional coactivator PGC-1. FASEB Journal 16 $1879-1886$.

Bae MK, Kwon YW, Kim MS, Bae SK, Bae MH, Lee YM, Kim YJ \& Kim KW 1998 Identification of genes differentially expressed by hypoxia in hepatocellular carcinoma cells. Biochemical and Biophysical Research Communications 243 158-162.

Bradford MM 1976 A rapid and sensitive method for the quantitation of microgram quantities of protein utilizing the principle of protein-dye binding. Analytical Biochemistry 72 248-254.

Burchiel SW, Edwards BS, Kuckuck FW, Lauer FT, Prossnitz ER, Ransom JT \& Sklar LA 2000 Analysis of free intracellular calcium by flow cytometry: multiparameter and pharmacologic applications. Methods 21 221-230.

Capaldi RA $1990 a$ Structure and assembly of cytochrome $c$ oxidase. Archives of Biochemistry and Biophysics 280 252-262.

Capaldi RA $1990 b$ Structure and function of cytochrome $c$ oxidase. Annual Review of Biochemistry 59 569-596.

Chandra D, Liu JW \& Tang DG 2002 Early mitochondrial activation and cytochrome $c$ up-regulation during apoptosis. Journal of Biological Chemistry 277 50842-50854.

Chandrasekaran K, Hatanpaa K, Brady DR, Stoll J \& Rapoport SI 1998 Down-regulation of oxidative phosphorylation in Alzheimer disease: loss of cytochrome oxidase subunit mRNA in the hippocampus and entorhinal cortex. Brain Research 796 13-19.

Choi YS, Lee HK \& Pak YK 2002 Characterization of the $5^{\prime}$-flanking region of the rat gene for mitochondrial transcription factor $\mathrm{A}$ (Tfam). Biochimica et Biophysica Acta 1574 200-204.

Dayanithi G, Rage F, Richard P \& Tapia-Arancibia L 1995 Characterization of spontaneous and $\mathrm{N}$-methyl-D-aspartate-induced calcium rise in rat cultured hypothalamic neurons. Neuroendocrinology 61 243-255.

Dong X, Ghoshal K, Majumder S, Yadav SP \& Jacob ST 2002 Mitochondrial transcription factor $\mathrm{A}$ and its downstream targets are up-regulated in a rat hepatoma. Journal of Biological Chemistry 277 43309-43318.

Fiske BK \& Brunjes PC 2001 NMDA receptor regulation of cell death in the rat olfactory bulb. Journal of Neurobiology 47 223-232.

Gleyzer N, Vercauteren K \& Scarpulla RC 2005 Control of mitochondrial transcription specificity factors (TFB1M and TFB2M) by nuclear respiratory factors (NRF-1 and NRF-2) and PGC-1 family coactivators. Molecular and Cellular Biology 25 1354-1366.

Hsu HK, Yang RC, Shih HC, Hsieh YL, Chen UY \& Hsu C 2001 Prenatal exposure of testosterone prevents SDN-POA neurons of postnatal male rats from apoptosis through NMDA receptor. Journal of Neurophysiology 86 2374-2380.
Hsu HK, Shao PL, Tsai KL, Shih HC, Lee TY \& Hsu C 2005 Gene regulation by NMDA receptor activation in the SDN-POA neurons of male rats during sexual development. Journal of Molecular Endocrinology 34 433-445.

Hwang JY, Kim YH, Ahn YH, Wie MB \& Koh JY 1999 N-Methyl-Daspartate receptor blockade induces neuronal apoptosis in cortical culture. Experimental Neurology 159 124-130.

Ikonomidou C, Bosch F, Miksa M, Bittigau P, Vockler J, Dikranian K, Tenkova TI, Stefovska V, Turski L \& Olney JW 1999 Blockade of NMDA receptors and apoptotic neurodegeneration in the developing brain. Science 283 70-74.

June CH \& Rabinovitch PS 1994 Intracellular ionized calcium. Methods in Cell Biology 41 149-174.

Kain KH, Popov VL \& Herzog NK 2000 Alterations in mitochondria and mtTFA in response to LPS-induced differentiation of B-cells. Biochimica et Biophysica Acta 1494 91-103.

Kanke M, Masato F, Ohno Y, Tokumaru Y, Imanishi Y, Tomita T, Inuyma Y \& Kanzaki J 1998 Result of treatment of squamous cell carcinoma of the tongue and floor of the mouth. Nippon Jibiinkoka Gakkai Kaiho 101 586-594.

Kristal BS \& Dubinsky JM 1997 Mitochondrial permeability transition in the central nervous system: induction by calcium cycling-dependent and -independent pathways. Journal of Neurochemistry 69 524-538.

Lawson MA, Whyte DB, Eraly SA \& Mellon PL 1995 Hypothalamusspecific regulation of gonadotropin-releasing hormone gene expression. Recent Progress in Hormone Research 50 459-463.

Mahesh VB, Zamorano P, De Sevilla L, Lewis D \& Brann DW 1999 Characterization of ionotropic glutamate receptors in rat hypothalamus, pituitary and immortalized gonadotropin-releasing hormone (GnRH) neurons (GT1-7 cells). Neuroendocrinology 69 $397-407$.

Ojuka EO 2004 Role of calcium and AMP kinase in the regulation of mitochondrial biogenesis and GLUT4 levels in muscle. Proceedings of the Nutrition Society 63 275-278.

Ojuka EO, Jones TE, Han DH, Chen M \& Holloszy JO 2003 Raising $\mathrm{Ca}^{2+}$ in L6 myotubes mimics effects of exercise on mitochondrial biogenesis in muscle. FASEB Journal 17 675-681.

Portilla D, Dai G, McClure T, Bates L, Kurten R, Megyesi J, Price P \& Li S 2002 Alterations of PPAR $\alpha$ and its coactivator PGC-1 in cisplatin-induced acute renal failure. Kidney International 62 12081218.

Schulz JB, Huang PL, Matthews RT, Passov D, Fishman MC \& Beal MF 1996 Striatal malonate lesions are attenuated in neuronal nitric oxide synthase knockout mice. Journal of Neurochemistry 67 430-433.

See V, Boutillier AL, Bito H \& Loeffler JP 2001 Calcium/calmodulindependent protein kinase type IV (CaMKIV) inhibits apoptosis induced by potassium deprivation in cerebellar granule neurons. FASEB Journal 15 134-144.

Siegel SJ, Brose N, Janssen WG, Gasic GP, Jahn R, Heinemann SF \& Morrison JH 1994 Regional, cellular, and ultrastructural distribution of $\mathrm{N}$-methyl-D-aspartate receptor subunit 1 in monkey hippocampus. PNAS 91 564-568.

Tracy RL \& Stern DB 1995 Mitochondrial transcription initiation: promoter structures and RNA polymerases. Current Genetics 28 205-216.

Urbanski HF, Fahy MM, Daschel M \& Meshul C 1994 N-methyl-Daspartate receptor gene expression in the hamster hypothalamus and in immortalized luteinizing hormone-releasing hormone neurones. Journal of Reproduction and Fertility 100 5-9.

Vijayasarathy C, Damle S, Prabu SK, Otto CM \& Avadhani NG 2003 Adaptive changes in the expression of nuclear and mitochondrial encoded subunits of cytochrome $c$ oxidase and the catalytic activity during hypoxia. European Journal of Biochemistry 270 871-879.

Wong-Riley MT 1989 Cytochrome oxidase: an endogenous metabolic marker for neuronal activity. Trends in Neurosciences 12 94-101.

Wu Z, Puigserver P, Andersson U, Zhang C, Adelmant G, Mootha V, Troy A, Cinti S, Lowell B, Scarpulla RC et al. 1999 Mechanisms controlling mitochondrial biogenesis and respiration through the thermogenic coactivator PGC-1. Cell 98 115-124. 
Wu H, Kanatous SB, Thurmond FA, Gallardo T, Isotani E, Bassel-Duby R \& Williams RS 2002 Regulation of mitochondrial biogenesis in skeletal muscle by CaMK. Science 296 349-352.

Yang RC, Shih HC, Hsu HK, Chang HC \& Hsu C 2003 Estradiol enhances the neurotoxicity of glutamate in GT1-7 cells through an estrogen receptor-dependent mechanism. Neurotoxicology $\mathbf{2 4}$ $65-73$.

Yano S, Tokumitsu H \& Soderling TR 1998 Calcium promotes cell survival through CaM-K kinase activation of the protein-kinase-B pathway. Nature 396 584-587.

Yoon WJ, Won SJ, Ryu BR \& Gwag BJ 2003 Blockade of ionotropic glutamate receptors produces neuronal apoptosis through the Baxcytochrome C-caspase pathway: the causative role of $\mathrm{Ca}^{2+}$ deficiency. Journal of Neurochemistry 85 525-533.
Zhang C \& Wong-Riley MT 2000 Synthesis and degradation of cytochrome oxidase subunit mRNAs in neurons: differential bigenomic regulation by neuronal activity. Journal of Neuroscience Research 60 338-344.

Zhang C, Shen W \& Zhang G $2002 \mathrm{~N}$-methyl-D-aspartate receptor and L-type voltage-gated $\mathrm{Ca}(2+)$ channel antagonists suppress the release of cytochrome $c$ and the expression of procaspase-3 in rat hippocampus after global brain ischemia. Neuroscience Letters 328 265-268.

Received in final form 5 April 2007

Accepted 15 May 2007

Made available online as an Accepted Preprint 18 May 2007 